\title{
Rural Poverty in Botswana: A Gendered Analysis
}

\author{
Khaufelo Raymond Lekobane, Keneilwe S. Mooketsane \\ Botswana Institute for Development Policy Analysis (BIDPA), Botswana \\ Public Administration, University of Botswana, Botswana \\ rlekobane@bidpa.bw
}

\begin{abstract}
We model the determinants of rural poverty in Botswana by conducting an empirical analysis of household welfare using the 2009/10 Botswana Core Welfare Indicator survey (BCWIS) to identify such factors associated with rural poverty. The paper found that female headed households, especially those residing in rural areas have higher incidences of poverty than male headed households. The study also found gender (male), education, employment, livestock ownership and access to amenities as factors that positively related with welfare for all rural households and the results were consistent across both FHHs and MHHs models, except for a few factors such as livestock ownership. Household size and dependency ratios negatively related with welfare. However, dependency ratio did not influence welfare amongst MHHs since such households are characterised by fewer dependents unlike the FHHs. Creation of employment opportunities in rural areas is key in helping the government in its poverty eradication efforts in rural areas. The paper also concludes that FHHs in rural areas must be made a special target of poverty eradication programmes, and a well focused gender specific intervention for poverty eradication initiatives is needed. Moreover, rural development strategies should emphasize the provision of agricultural infrastructure, promotion of agricultural productivity growth through improved technology adoption, as well as provision of basic services such as water, sanitation and electricity in rural areas.
\end{abstract}

Keywords: Botswana, Rural poverty, Welfare, Agriculture, Consumption

\section{Introduction}

Poverty in Botswana is a rural phenomenon. The country has a total population of about 2 million people, with about 37\% (748,762) residing in rural areas (Statistics Botswana, 2013a). Agriculture has always been the backbone of the economy since independence in 1966, contributing about 40\% of the GDP (Seleka, 2004). However, agriculture has declined in relative economic importance. This sector is mainly based on smallholder farms and contributes about $2.3 \%$ of the country's GDP and employs about $15.3 \%$ of the total labour force (Statistics Botswana, 2013b; Statistics Botswana, 2014). Agriculture is the predominant activity for the many rural households in Botswana. However, this sector has been characterized by decreasing farm sizes, low levels of output per farm, low productivity, a high degree of subsistence farming, with increases in production being driven mainly by area and not yields growth (Transtec \& BIDPA, 2010). The declining in agricultural productivity is also associated with among other things intermittent rainy seasons, persistent droughts, lack of draught power and lack of proper agricultural technology. This has brought about serious economic and social challenges in rural areas; the biggest challenge being high poverty rates. According to Statistics Botswana (2013b) rural poverty rate stood at $24.3 \%$ compared to $19.9 \%$ and $8 \%$ of urban villages and cities/towns, respectively. Rural poverty accounts for about $54 \%$ of the total poor. . Analyzing rural poverty through the gender lens depicted an interesting picture. Poverty is more prevalent across FHHs (22.4\%) than MHHs (16.2\%) and the difference is higher in rural areas with female headcount estimated at $26.9 \%$ compared to $21.6 \%$ for males.

Several poverty profiles with descriptive analysis of the characteristics of the poor have been produced for Botswana (Watanabe and Mueller, 1984; BIDPA, 1996; CSO, 2008; Statistics Botswana, 2013a). While there is evidence that rural poverty has declined and that poverty reduction has been widely recognised as top priority on the government development agenda, little quantitative work has been done to explore poverty profiles through a gender lens and explain determinants of rural poverty. Past studies that looked at the determinants of rural poverty did not employ a nationally representative dataset but rather looked at village case study (Moepeng \& Tisdell 2008). This paper therefore, conducts an econometric analysis of the determinants of rural poverty in Botswana using the 2009/10 Botswana Core Welfare Indicator 
Survey (BCWIS). The rest of the paper is organized as follows. Section 2 profiles the rural poor and in section 3 we describe the conceptual model of the determinants of rural poverty in Botswana and we discuss our primary data sources in section 3. In section 4 we present the empirical model, introduce the set of regressors and their descriptive statistics. The results of the model are presented and discussed in section 5 whilst section 6 concludes and provides policy implications.

\section{Characteristics of the Rural Poor}

We profile the demographic and economic characteristics of the rural households in order to identify factors associated with rural poverty and also compare the differentials by gender. These profiles are a useful way of summarizing on the levels of poverty across gender and the characteristics of the poor in the society (Datt \& Jolliffe, 2005). They also give us clues to the underlying determinants of poverty. These profiles are presented in Table A4 (Annex).

Generally, poverty is more prevalent among individuals residing in FHHs across all age groups, especially those households headed by children (12-17 years), except for the elderly headed households $(65+)$, where poverty was higher among those headed by males. With regard to marital status, rural poverty is highest among individuals residing in female single headed households (separated, divorced, widowed and the never married). The share of the total poor of FHHs ranged between $81 \%$ and $97 \%$ amongst the single headed households. The incidences of poverty were also very high in such households compared to similar households headed by males. For example, the headcount ratio of individuals residing in households headed by widows stood at $29.6 \%$ for FHHs compared to only $8.3 \%$ for MHHs.

Poverty in rural areas is higher across households whose heads have lower educational attainments. The incidences are even more widespread across FHHs than MHHs. For example, for those individuals whose heads never attended school, the incidence of poverty stood at $34.2 \%$ for FHHs compared to $27.5 \%$ for MHHs. The share of FHHs to the total poor was also high at 56\%. Profiling rural poverty by employment categories revealed higher incidences of poverty amongst FHHs than MHHs across employment categories except for those working in their own farms where the incidence of poverty was higher amongst MHHs. The incidence of poverty was highest amongst the unemployed, especially those residing in FHHs than those in MHHs. Similarly, the share of FHHs to the total unemployed poor accounted for the largest share of about 70\%. As expected, poverty was lowest across the unemployed and the rates were comparable across both FHHs and MHHs. Poverty incidences are lower amongst households relying on paid employment as their main source of income. However, households whose main source of income was off-farm income (sale of harvesting of natural resources, piece jobs) had higher incidences of poverty and the rates were higher amongst FHHs than MHHs. This was followed by households whose main source of income was farm income and government assistance, the majority of which were FHHs. Similarly, the incidences of poverty declined with increases in cattle herd sizes and small stock an indication that livestock plays an important role in rural poverty.

Overall, poverty increases with increase in household size and the increase is higher amongst FHHs than amongst MHHs. For example, the incidence of poverty amongst FHHs with members from 4 to 5 is $21.8 \%$ compared to $13.8 \%$ for MHHs. Similarly, for FHHs with more than 16 members, poverty rate stood at $100 \%$ compared to $28.1 \%$ for MHHs with the same members. Generally, individuals residing in households with no access to basic amenities like electricity, safe drinking water and sanitation had higher incidences of poverty across all households, irrespective of the gender of household head. The share of the poor was higher amongst households with no access to electricity ranging from $91 \%$ to about 93\% with FHHs accounting for the largest share. This is expected, since the majority of the poor in rural areas have limited resources to pay for electricity connections. The headcount index stood at $19.3 \%$ at national level and rural headcount stood at $24.3 \%$ compared to $19.9 \%$ and $8 \%$ of urban villages and cities/towns, respectively (Statistics Botswana, 2013). Overall, rural poverty accounted for about 54\% of the total poor, and across gender rural FHHs accounted for the largest share of the total female poor. Analyzing rural poverty through the gender lens depicted an interesting picture. Poverty is more prevalent across FHHs (22.4\%) than MHHs (16.2\%) and the difference is higher in rural areas with female headcount estimated at $26.9 \%$ compared to $21.6 \%$ for males. 


\section{Conceptual Model of Rural Poverty and Data Sources}

There can be a number of different approaches to modeling the determinants of poverty. This paper adopts the per capita consumption approach to model the determinants of household poverty. Per capita consumption is used as a proxy to measure the household welfare. This approach involves regressing the natural logarithm of per capita consumption against a series of independent variables using the ordinary least squares (OLS) estimation procedure and has been used elsewhere in the developing world (Lekobane \& Seleka, 2014; Akerele \& Adewuyi, 2011; Litchfield \& McGregor, 2008; Datt \& Jolliffe, 2005; Mukherjee \& Benson, 2003). The simplest form of such a model can be expressed as follows:

$$
\ln c_{j}=\beta^{\prime} x_{j}+\varepsilon_{j}
$$

Where $c_{j}$ denotes per capita consumption for household $j, x_{j}$ is a set of explanatory variables used, $\beta^{\prime}$ is the set of parameters to be estimated and $\varepsilon_{j}$ is a random error term. The study uses the nationally representative 2009/10 Botswana Core Welfare Indicator Survey (BCWIS) data collected by Statistics Botswana. The BCWIS collected information from 7732 households, selected from rural areas, urban villages and cities/towns. However, since the study is interested in rural poverty, we only selected 3,251 rural households for the analysis. The questionnaires were administered using a two-stage, stratified selection process ${ }^{1}$.

Empirical Model: In modelling the determinants of rural household welfare, we estimate three separate models for all rural households, FHHs and MHHs. We do this in order to make comparisons of the significance and effect of variables used across the models and to check if the results of FHHs and MHHs are consistent with the overall model for all households. In this study, we use the natural logarithm of per capita consumption expenditure as the dependent variable in the welfare model. This variable (unlogged) is used as a measure of welfare. To derive per capita consumption for a household, we divided total consumption expenditure by the number of individuals in the household. This welfare measure assumes equal allocation of items consumed by household members, and that every household member has the same needs irrespective of age or gender. It also assumes that the cost of two or three people living together is the same as if they lived separately (Mukherjee \& Benson, 2003).

The choice of independent variables was largely guided by the empirical literature on the determinants of welfare and poverty in developing countries. The independent variables used in the study together are defined in Table A1, with their descriptive statistics presented in Table A2 in the Annex. These variables are broadly grouped into $\mathrm{HH}$ characteristics, household characteristics, and household main source of income and livestock ownership. We also included dummy variables to capture household access to basic amenities. Under HH characteristics, we included age (linear and quadratic terms), gender, marital status and education and employment status of the household head. Age of $\mathrm{HH}$ averaged 50 years, an indication that most of the households in rural areas are headed by older people. However, there are households headed by children as young as 13 years and this could be orphan children. About $53 \%$ of household in rural areas are male headed. About $34 \%$ of households head were never married, followed by married heads with $26 \%$ and cohabiting couples (living together) with $20 \%$. The widowed accounted for about $16 \%$ and the divorced and separated accounted for the remaining $4 \%$. The majority of households' heads in rural areas have lower educational attainments with an average of about 5 years of schooling, implying the majority did not have even primary school leaving certificate (less than primary). With regard to employment status, about 38\% were involved in paid employment, $38 \%$ worked in own land/cattle post and a paltry $5 \%$ were involved in self employment whilst $4 \%$ worked as unpaid family helpers. The remaining $34 \%$ of rural household heads were unemployed.

Household characteristics included household size (linear and quadratic terms) and dependency ratio (measured as the number of individuals aged 0 to 14 years and 65 years and above as a ratio of those aged 15 to 64 years). The average household size in rural areas averaged 3.6 and dependency ratio recorded more than 1, implying that there are more dependents in rural households than the economic active members. We also included income dummies to capture the main sources of income for rural households. These included dummies for pensions, remittances, government assistance, off-farm income,

\footnotetext{
${ }^{1}$ For more information on the BCWIS see Statistics Botswana (2013a) and Lekobane and Seleka (2014)
} 
off-farm business, farm income and wages from employment (reference variable). Clearly, the majority of rural households rely on wages from employment as their main source of income $(44 \%)$ followed by pensions and remittances with $16 \%$ and $14 \%$, respectively. The remaining households relied on government assistance (6\%), off farm income (7\%), off farm business (8\%) and lastly farm income (5\%).

To capture livestock ownership, three dummy variables were used for cattle, goats and sheep ownership. About $38 \%$ of rural households reared cattle whilst $42 \%$ and $10 \%$ reared goats and sheep, respectively. Three dummy variables were included to capture household access to basic amenities; access to electricity, safe drinking water and sanitation. Only $21 \%$ of rural household were connected to electricity and $71 \%$ and $64 \%$ had access to safe drinking sanitation, respectively.

\section{Results and Discussion}

Table 2 presents the estimated results of the welfare models for all rural households, FHHs and MHHs. Since the dependent variables are in log form, the estimated regression coefficients for continuous variables measure the percentage change in household welfare due to a unit increase in the independent variable (Giles, 2011; Halvorsen \& Palmquist, 1980; Lekobane \& Seleka, 2014). However, for categorical (dummy) variables, the percentage change in welfare due to the change in the considered binary variable from a value of 0 to 1 is computed as: $100\left(e^{\alpha}-1\right)$, where $\alpha$ represents the estimated coefficient for the considered independent variable (Seleka \& Lekobane, 2014; Giles, 2011; Halvorsen \& Palmquist, 1980). The independent variables for the full model (all rural households) account for about $43 \%$ of the total variation in the dependent variable and for FHHs and MHHs they accounted for about $40 \%$ and $43 \%$, respectively. The F-statistics for the three models were highly significant $(\mathrm{p}<0.001)$, implying that the explanatory variables jointly exert significant influence on household welfare for all rural households, FHHs and MHHs.

Household Head Characteristics: The estimated coefficient for age of household head is positive and that of age squared is negative (for all the three models). This conforms to the findings of previous studies, and indicates that as age of the household head increases, welfare increases at a decreasing rate, reaches a maximum and declines at old age (Datt \& Jolliffe, 2005; Lekobane \& Seleka, 2014). This is consistent with the life-cycle phenomenon of higher earning capacity with greater experience and smoothing of consumption over the life cycle (Datt \& Jolliffe, 2005). However, for the FHHs model, the two variables are not statistically significant. MHHs attained welfare than FHHs, an indication that rural households headed by males are better-off in terms economic welfare than those headed by females. This may suggest that the empowerment of women, especially in rural areas will be fundamental in achieving improvements in rural household welfare and reduction in rural poverty. Generally, marriage enhances household welfare. Households whose heads were cohabiting (living together) attained 9\% lower per capita than households with married HHs. Similarly, households whose heads were never married attained 18\% lower per capita consumption than those with married HHs. However, the results indicate that household welfare for separated, divorced and widowed HHs did not statistically differ from that for households headed by married HHs.

Education level of the household head is highly significant and has a positive sign, as hypothesized. This indicates that the higher the level of education of household head, the higher the household welfare. A one year increase in the level of education of the rural household head resulted in $4.9 \%, 5.7 \%$ and $4.1 \%$ increase in welfare for all rural households, FHHs and MHHs, respectively. This is expected as education improves economic performance of the household as a whole and in addition to agricultural activities which forms an important rural livelihood activity. Rural households with higher educational levels are more likely to adopt new farming technologies to increase agricultural productivity. Households headed by individuals engaged in paid employment and self-employed attained $22 \%$ and $45 \%$, respectively, higher welfare than those whose heads were not engaged in any type of work. However, the results indicate that household welfare for households whose heads were unpaid family workers or selfemployed in agriculture (working in own lands/ cattle posts) did not statistically differ from those households whose were not engaged in any type of work.

Household Characteristics: Household size has a negative effect on rural household welfare. The inverse relationship between household size and welfare, indicating that an average household with small household size is better in terms of welfare than a larger household and this is a common finding in the 
empirical literature (Lekobane \& Seleka, 2014; Datt \& Jolliffe, 2005). However, household size squared has a positive effect on welfare, implying that there may be economies of scale associated with larger households. The results are consistent across the three models. Dependency ratio also negatively influences rural household welfare, suggesting that an increase in the dependency ratio would result in a reduction in welfare. However, this variable is not statistically significant for the MHHs model, and this is not surprising since the majority of rural households headed by males are characterized by smaller household sizes with less dependents (children and the elderly), who are mostly found in FHHs. For example, household size averaged about 4 for FHHs compared to 3 for MHHs (Statistics Botswana, 2013).

Table 4: OLS Regression results for the three welfare models

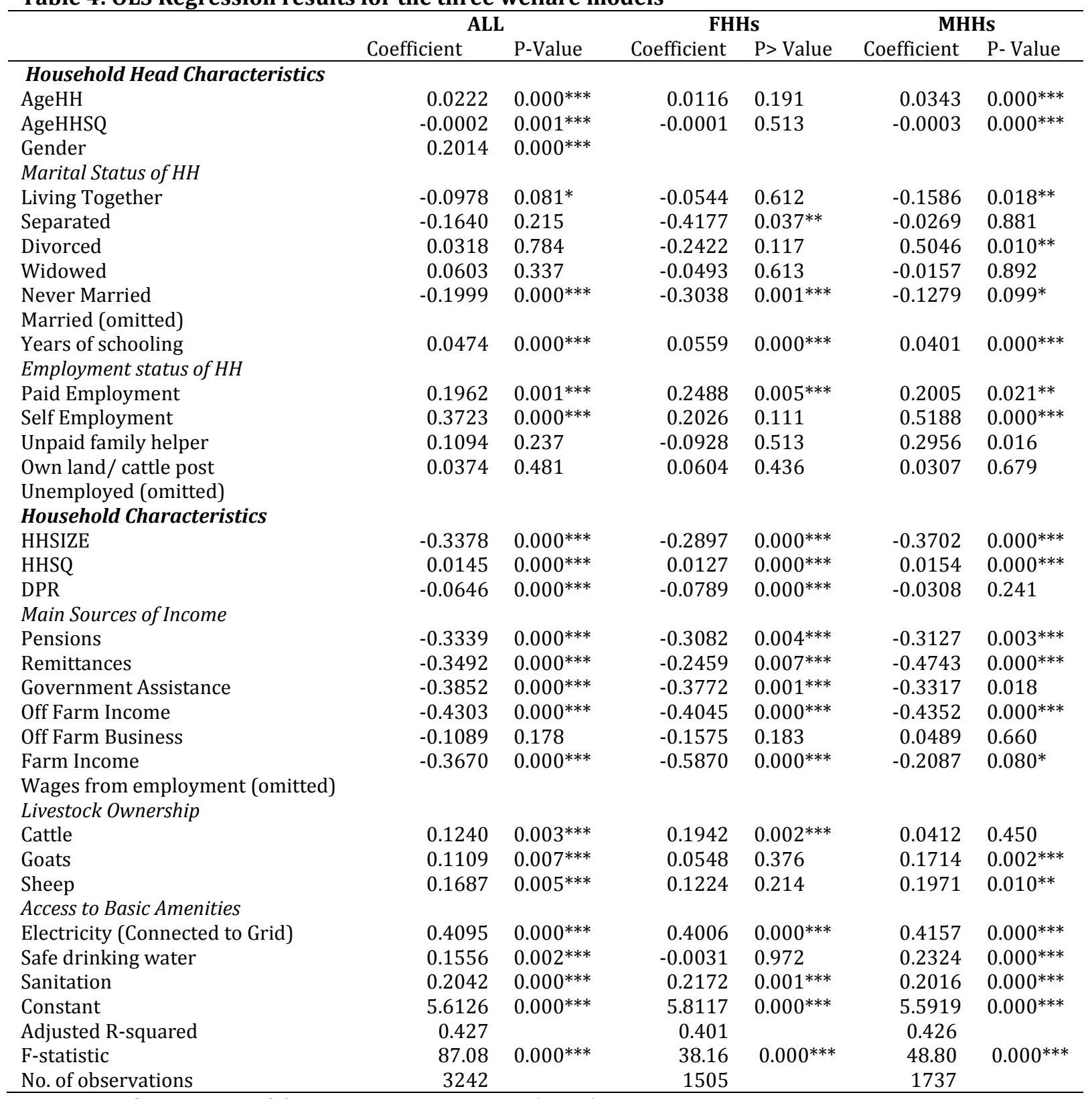

Source: Author computed from Statistics Botswana (2013)

$* * *, * *$ and *: statistically significant at 1,5 and 10 percent, respectively

Main Sources of Household Income: The results show that households whose main source of income is transfers (pensions, remittances and government assistance) had lower welfare compared to those whose main source of income was wage employment. This is expected since transfers are normally smaller compared to wages from employment. However, government assistance is not significant for MHHs model. Similarly, households whose main source of income is off-farm income and farm income 
attained lower welfare than those whose main source of income is wage employment. Clearly this is an indication that wage income is key in welfare improvement for all rural households. Therefore creation of employment opportunities in rural areas is key in helping the government in its poverty eradication efforts. In sum, rural poverty could be addressed if non-agricultural activities emerged to provide off-farm employment opportunities to rural dwellers. Provision of short-term employment such as Ipelegeng ${ }^{2} \mathrm{can}$ also help alleviate rural poverty.

Livestock Ownership: Livestock ownership enhances welfare and also serves as source of income for rural households. The results show that households owning cattle, goats and sheep, respectively, attained $13 \%, 12 \%$ and $18 \%$ welfare compared to households who did not own any livestock. This is expected because ownership of livestock can generate cash income through sales, which results in increased consumption. Livestock also serve as a source of food security for rural households, especially small stock (sheep and goats). However, small stock (goats and sheep) rearing do not significantly influence household welfare for FHHs and this could be attributed to the fact that FHHs rear small herd-sizes compared to their male counterparts, where the two variables are highly significant and positively relates with welfare. An interesting observation is with regard to cattle ownership where it positively related and significantly related with welfare in the full model and FHHs model but was insignificant in the MHHs model. This could be related to the fact that in rural areas especially, male heads rear cattle as a form of pride than for commercial use whereas for females it is a source of livelihoods through sales.

Access to Basic Amenities: Results show that having access to amenities increases one's welfare. Households connected to electricity grid have higher welfare compared to those not connected to the grid. Similarly, households with access to safe drinking water have higher welfares compared to those with no access to portable water. In the same token, household with access to safe sanitation facilities have higher welfare than those with no access to safe sanitation. This is expected since access to basic amenities such as electricity and sanitation may be related to the income level of the household and hence increases in welfare.

\section{Conclusions and Policy Implications}

Poverty in Botswana is a rural phenomenon. We modelled the determinants of rural household poverty by conducting an empirical analysis of household welfare using the 2009/10 Botswana Core Welfare Indicator Survey (BCWIS) dataset in order to identify such factors associated with rural poverty. Rural households headed by males are better-off in terms of economic welfare than those headed by females. Therefore, initiatives of empowerment of women in rural areas are fundamental in achieving improvements in rural household welfare and reduction in rural poverty. Increased emphases should also be placed on improving the quality of education services in rural areas which still lag behind in terms of the provision of quality education. Efforts to diversify the Botswana economy and expand employment opportunities should be intensified. Since rural households are characterized by larger families, awareness building on reproductive health knowledge that could empower household heads to make quality decision regarding their family size may be useful. There is a need to intensify family planning initiatives in rural areas.

Those policies to promote accumulation of assets especially agricultural assets such as livestock (cattle, goats, and sheep) would accelerate poverty reduction. Livestock plays an important part in improving rural livelihood. Some kinds of livestock such as small stock (goats/sheep) and poultry could be the source of daily nutrition for household consumption and may sometimes be used as source of household income through sales. Other livestock such as cattle may be used as draught power during ploughing seasons and in income generation. However, the challenge could be on how to change such traditional ways of rearing livestock to a strategy to increase income and reduce poverty. To achieve this, there is need for provision of better animal health extension services to better the livelihoods of rural dwellers. Moreover, rural development strategies should emphasize the provision of agricultural infrastructure, promotion of agricultural productivity growth through improved technology adoption, especially that the majority of FHHs derive their livelihoods from subsistence farming.

\footnotetext{
2 Ipelegeng is a poverty eradication programme introduced in 2008 by government to provide employment opportunities for the poor and the unemployed. Unlike the previous drought relief programme which was temporary, Ipelegeng is a permanent programme.
} 
Ensuring sustainable access to water and sanitation is also key to enable girls and women to participate in education and employment. Universal access to sexual and reproductive health and rights is also fundamental to reducing poverty in rural areas, including by reducing maternal mortality and enabling women to control the timing and number of their children Finally, in rural areas with a high level of male out-migration, FHHs must be made a special target of poverty eradication programmes, and well focused gender specific interventions for poverty eradication initiatives are needed. In responding to the needs and priorities of the rural poor it is important to shift from broad based policies to targeting specific social groups and addressing particular constraints faced by such specific groups.

\section{References}

Akerele, D. and Adewuyi, A.S. (2011). Analysis and Profiles and Socioeconomic Determinants of Welfare among Urban Households of Ekiti State, Nigeria. Current Research Journal of Social Sciences, 3(1), $1-7$.

BIDPA. (1996). The Study of Poverty and Poverty Alleviation in Botswana. Unpublished Consultancy Report. Gaborone: Botswana Institute for Development Policy Analysis (BIDPA).

BIDPA. (2010). Review of the National Strategy for Poverty Reduction: Social Protection for Poverty and Vulnerability Reduction. Unpublished Consultancy Report. Gaborone: Botswana Institute for Development Policy Analysis (BIDPA).

Central Statistics Office. (2008). Poverty Datum Line for Botswana 2003. Central Statistics Office (CSO), Gaborone.

Datt G and Jolliffe, D. (2005). Poverty in Egypt: Modelling and Simulation. Economic Development and Cultural Change, 53(2), 327-346.

Giles, D. E. (2011). Interpreting Dummy Variables in Semi-logarithmic Regression Models: Exact Distributional Results. Econometric Working paper EWP1101. University of Victoria, Canada.

Grootaert, C. (1997). The Determinants of Poverty in Cote d'Ivore in the 1980s. Journal of African Economics, 6(2), 169-96.

Halvorsen, R. and Palmquist, R. (1980). The interpretation of dummy variables in semi-logarithmic equations. American Economic Review, 70(3), 474-475.

Lekobane, K. R. and Seleka, T. B. (2014). Determinants of household welfare and poverty in Botswana, 2002/03 and 2009/10, BIDPA Working paper No. 38. BIDPA, Gaborone.

Litchfield, J. and McGregor, T. (2008). Poverty in Kagera, Tanzania: Characteristics, Causes and Constraints. PRUS Working paper No.42. University of Sussex, Brighton. United Kingdom.

Moepeng, P., and Tisdell C. M. (2008). The socio- economic situation of Female heads and Poor heads of households in rural Botswana: A village Case Study. Social Economics, Policy and Development. University of Queensland, working paper No 48.

Mukherjee, S. and Benson, T. (2003). The determinants of poverty in Malawi, 1998. World Development, 33(2), 339-358.

Seleka, T. B., 2004. Diversification in Botswana's Agricultural Sector: Issues, Prospects and Challenges. Botswana Institute for Development Policy Analysis, Gaborone, Botswana. BIDPA Publication Series, 28pp. ISBN: 99912-65-25-2.

Seleka, T. B. and Lekobane, K. R. (2014). Public Transfers and Subsistence Producer Disincentives in Botswana, BIDPA working paper No. 37. BIDPA, Gaborone.

Transtec and BIDPA. (2010). Agricultural Sector Review, Unpublished Consultancy Report, Gaborone: Botswana Institute for Development Policy Analysis (BIDPA) (2010).

Statistics Botswana, (2013). Botswana Core Welfare Indicator Survey 2009/10 Final Report. Statistics Botswana, Gaborone.

Statistics Botswana, (2014). 2011 Population and Housing Census Dissemination Draft Report. Statistics Botswana, Gaborone.

Watanabe, B. and Mueller, E. (1984). A poverty profile for rural Botswana. World Development, 12(2), 115-127.

World Bank and BIDPA (2013). Botswana Social Protection Assessment. The World Bank and BIDPA. Gaborone, Botswana. 


\section{Appendix}

Table A1: Variable used in the model and their descriptions

\begin{tabular}{|c|c|}
\hline Variables & Description \\
\hline Welfare (c) & Per capita consumption (BWP) \\
\hline \multicolumn{2}{|l|}{ Household Head Characteristics } \\
\hline AgeHH & Age of household head \\
\hline AgeHHSQ & Age of household squared \\
\hline Gender & Gender of household head; $1=$ male household head \\
\hline \multicolumn{2}{|l|}{ Marital Status of $H H$} \\
\hline Living Together & $1=$ household head is cohabiting (living together), 0 otherwise \\
\hline Separated & $1=$ household head is separated, 0 otherwise \\
\hline Divorced & $1=$ household head is divorced, 0 otherwise \\
\hline Widowed & $1=$ household head is widowed, 0 otherwise \\
\hline Never Married & $1=$ household head never married, 0 otherwise \\
\hline Married (omitted) & Reference variable ( $1=$ household head is married) \\
\hline Years of schooling & Number of years schooling \\
\hline \multicolumn{2}{|l|}{ Employment status of $\mathrm{HH}$} \\
\hline Paid Employment & $\begin{array}{l}1=\text { household head is engaged in formal paid employment, } 0 \\
\text { otherwise }\end{array}$ \\
\hline Self Employment & $\begin{array}{l}1=\text { household head is engaged is self employed, } 0 \text { otherwise } \\
1=\text { household head is engaged is unpaid family helper, } 0\end{array}$ \\
\hline Unpaid family helper & otherwise \\
\hline Own land/ cattle post & $1=$ household head works in own land/ cattle post, 0 otherwise \\
\hline Unemployed & Reference variable ( 1 if head not working, 0 otherwise) \\
\hline \multicolumn{2}{|l|}{ Household Characteristics } \\
\hline HHSIZE & Household size \\
\hline HHSQ & Household size squared \\
\hline DPR & Dependency ratio \\
\hline \multicolumn{2}{|l|}{ Main Sources of Income } \\
\hline Pensions & $1=$ household main source of income is pension, 0 otherwise \\
\hline Remittances & $\begin{array}{l}1=\text { household main source of income is remittances, } 0 \text { otherwise } \\
1=\text { household main source of income is from government }\end{array}$ \\
\hline Government Assistance & assistance, 0 otherwise \\
\hline \multirow[t]{2}{*}{ Off Farm Income ${ }^{a}$} & $\begin{array}{l}\text { 1= household main source of income is off-farm income, } 0 \\
\text { otherwise }\end{array}$ \\
\hline & $1=$ household main source of income is from off-farm business, 0 \\
\hline Off Farm Business ${ }^{b}$ & otherwise \\
\hline Farm Income ${ }^{c}$ & $1=$ household main source of income is farm income, 0 otherwise \\
\hline Wages from employment & Reference variable \\
\hline \multicolumn{2}{|l|}{ Livestock Ownership } \\
\hline Cattle & 1= household has cattle, 0 otherwise \\
\hline Goats & 1= household has goats, 0 otherwise \\
\hline Sheep & $1=$ household has sheep, 0 otherwise \\
\hline \multicolumn{2}{|l|}{ Access to Basic Amenities } \\
\hline Electricity (Connected to Grid) & $1=$ household is connected with electricity (Grid) \\
\hline Safe drinking water & $1=$ household has access to safe drinking water \\
\hline Sanitation & 1=household has access to sanitation \\
\hline
\end{tabular}


Table A3: Descriptive statistics

\begin{tabular}{|c|c|c|c|c|c|c|}
\hline \multirow[b]{2}{*}{ Variables } & \multicolumn{2}{|c|}{ ALL } & \multicolumn{2}{|c|}{ FHHs } & \multicolumn{2}{|c|}{ MHHs } \\
\hline & Mean & $S D$ & Mean & $S D$ & Mean & $S D$ \\
\hline \multicolumn{7}{|l|}{ Household Head Characteristics } \\
\hline AgeHH & 50.00 & 18.07 & 51.62 & 17.79 & 48.60 & 18.20 \\
\hline Gender & 0.53 & 0.50 & - & - & - & - \\
\hline \multicolumn{7}{|l|}{ Marital Status of HH } \\
\hline Living Together & 0.20 & 0.40 & 0.14 & 0.34 & 0.25 & 0.43 \\
\hline Separated & 0.02 & 0.13 & 0.02 & 0.13 & 0.02 & 0.13 \\
\hline Divorced & 0.02 & 0.15 & 0.04 & 0.19 & 0.01 & 0.12 \\
\hline Widowed & 0.16 & 0.36 & 0.29 & 0.45 & 0.05 & 0.21 \\
\hline Never Married & 0.34 & 0.47 & 0.42 & 0.49 & 0.28 & 0.45 \\
\hline Married (omitted) & 0.26 & 0.44 & 0.10 & 0.31 & 0.40 & 0.49 \\
\hline Years of schooling & 4.53 & 4.84 & 4.54 & 4.77 & 4.53 & 4.91 \\
\hline \multicolumn{7}{|l|}{ Employment status of $\mathrm{HH}$} \\
\hline Paid Employment & 0.38 & 0.48 & 0.27 & 0.45 & 0.47 & 0.50 \\
\hline Self Employment & 0.05 & 0.23 & 0.06 & 0.24 & 0.05 & 0.22 \\
\hline Unpaid family helper & 0.04 & 0.19 & 0.03 & 0.18 & 0.04 & 0.20 \\
\hline Own land/ cattle post & 0.19 & 0.39 & 0.17 & 0.38 & 0.21 & 0.41 \\
\hline Unemployed & 0.34 & 0.42 & 0.47 & & 0.23 & \\
\hline \multicolumn{7}{|l|}{ Household Characteristics } \\
\hline HHSIZE & 3.63 & 2.83 & 4.03 & 2.77 & 3.29 & 2.84 \\
\hline DPR & 1.04 & 1.45 & 1.43 & 1.63 & 0.70 & 1.16 \\
\hline \multicolumn{7}{|l|}{ Main Sources of Income } \\
\hline Pensions & 0.16 & 0.37 & 0.18 & 0.38 & 0.15 & 0.36 \\
\hline Remittances & 0.14 & 0.35 & 0.20 & 0.40 & 0.09 & 0.29 \\
\hline Government Assistance & 0.06 & 0.23 & 0.08 & 0.27 & 0.04 & 0.19 \\
\hline Off Farm Income ${ }^{a}$ & 0.07 & 0.25 & 0.08 & 0.27 & 0.06 & 0.24 \\
\hline Off Farm Business ${ }^{b}$ & 0.08 & 0.27 & 0.09 & 0.29 & 0.07 & 0.26 \\
\hline Farm Income ${ }^{c}$ & 0.05 & 0.22 & 0.05 & 0.21 & 0.06 & 0.23 \\
\hline Wages from employment & 0.44 & 0.49 & 0.32 & 0.47 & 0.52 & 0.50 \\
\hline \multicolumn{7}{|l|}{ Livestock Ownership } \\
\hline Cattle & 0.38 & 0.49 & 0.29 & 0.46 & 0.46 & 0.50 \\
\hline Goats & 0.42 & 0.49 & 0.37 & 0.48 & 0.46 & 0.50 \\
\hline Sheep & 0.10 & 0.30 & 0.08 & 0.28 & 0.12 & 0.32 \\
\hline \multicolumn{7}{|l|}{ Access to Basic Amenities } \\
\hline Electricity (Connected to Grid) & 0.21 & 0.41 & 0.22 & 0.42 & 0.20 & 0.40 \\
\hline Safe drinking water & 0.77 & 0.42 & 0.86 & 0.34 & 0.69 & 0.46 \\
\hline Sanitation & 0.64 & 0.48 & 0.72 & 0.45 & 0.57 & 0.50 \\
\hline
\end{tabular}

Source: Author computed from Statistics Botswana (2013)

Based on the 3,242 households from rural areas. aff-farm income includes income from piece jobs/parttime, income from sale of harvested natural resources. bOff-farm business includes enterprise business, rental and interests earned and ${ }^{\mathrm{C} F a r m}$ income includes sale of livestock and crop produce. 


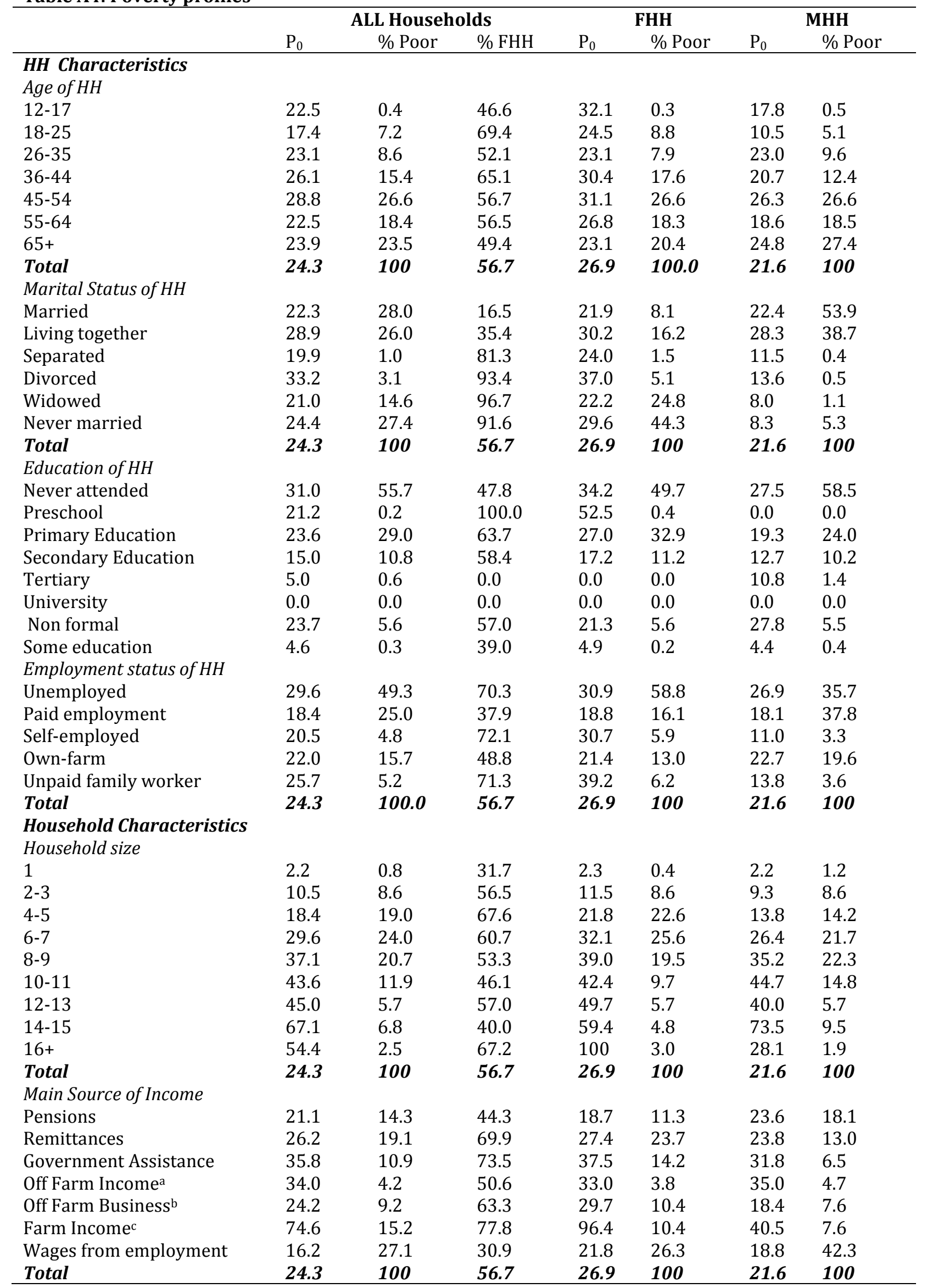


Livestock ownership

\begin{tabular}{|c|c|c|c|c|c|c|c|}
\hline 0 & 25.2 & 66.6 & 65.0 & 28.0 & 76.4 & 21.3 & 53.8 \\
\hline $1-19$ & 24.4 & 28.0 & 41.8 & 25.4 & 20.7 & 23.8 & 37.7 \\
\hline $20-39$ & 15.9 & 2.7 & 26.1 & 13.4 & 1.3 & 17.0 & 4.7 \\
\hline $40-59$ & 16.6 & 1.4 & 57.7 & 28.9 & 1.5 & 10.5 & 1.4 \\
\hline$>60$ & 18.2 & 1.2 & 10.0 & 8.2 & 0.2 & 21.1 & 2.5 \\
\hline \multicolumn{8}{|l|}{ Access to Basic Amenities } \\
\hline Electricity & 5.7 & 8.1 & 51.3 & 5.9 & 7.4 & 5.7 & 9.0 \\
\hline \multirow[t]{2}{*}{$(\mathrm{No})$} & 17.6 & 91.9 & 56.8 & 21.4 & 92.6 & 13.7 & 91.0 \\
\hline & 24.3 & 100 & 56.7 & 26.9 & 100.0 & 21.6 & 100 \\
\hline Safe drinking water (Yes) & 14.4 & 74.8 & 63.9 & 17.6 & 84.9 & 10.8 & 61.9 \\
\hline$(\mathrm{No})$ & 16.2 & 25.2 & 33.9 & 19.7 & 15.1 & 14.8 & 38.1 \\
\hline Total & 24.3 & 100 & 56.7 & 26.9 & 100.0 & 21.6 & 100 \\
\hline \multirow[t]{3}{*}{ Sanitation } & 12.4 & 50.1 & 63.3 & 14.9 & 59.8 & 9.5 & 44.8 \\
\hline & 21.6 & 49.9 & 42.7 & 25.5 & 40.2 & 15.4 & 55.2 \\
\hline & 24.3 & 100 & 56.7 & 26.9 & 100.0 & 21.6 & 100 \\
\hline \multicolumn{8}{|l|}{ Regional Dimensions } \\
\hline Cities/towns & 8.0 & 8.7 & 47.1 & 9.5 & 7.0 & 7.1 & 11.0 \\
\hline Urban villages & 19.9 & 37.1 & 63.0 & 22.9 & 40.2 & 16.2 & 32.9 \\
\hline Rural villages & 24.3 & 54.2 & 56.7 & 26.9 & 52.8 & 21.6 & 56.1 \\
\hline Total & 19.3 & 100 & 58.2 & 22.4 & 100 & 16.2 & 100 \\
\hline
\end{tabular}

Source: Author computed from Statistics Botswana (2013)

$\mathrm{P}_{0}$ is the poverty headcount ratio. ${ }^{\mathrm{a}}$ Off-farm income includes income from piece jobs/part-time, income from sale of harvested natural resources. bOff-farm business includes enterprise business, rental and interests earned and 'Farm income includes sale of livestock and crop produce. $\mathrm{HH}=$ household head 